\title{
PBX1 is dispensable for neural commitment of RA-treated murine ES cells
}

\author{
Anne S. Jürgens • Mateusz Kolanczyk • \\ Dietrich C. C. Moebest • Tomasz Zemojtel • \\ Urs Lichtenauer • Marlena Duchniewicz • \\ Melanie P. Gantert • Jochen Hecht • Uwe Hattenhorst • \\ Stefan Burdach • Annette Dorn • Mark P. Kamps • \\ Felix Beuschlein • Daniel Räpple • Jürgen S. Scheele
}

Received: 12 September 2008 / Accepted: 20 November 2008 /Published online: 16 January 2009 / Editor: J. Denry Sato

(C) The Society for In Vitro Biology 2009

\begin{abstract}
Experimentation with PBX1 knockout mice has shown that PBX1 is necessary for early embryogenesis. Despite broad insight into PBX1 function, little is known about the underlying target gene regulation. Utilizing the CreloxP system, we targeted a functionally important part of the homeodomain of PBX1 through homozygous deletion of
\end{abstract}

Jürgens and Kolanczyk contributed equally.

Electronic supplementary material The online version of this article (doi:10.1007/s11626-008-9162-5) contains supplementary material, which is available to authorized users.

A. S. Jürgens $\cdot$ M. Kolanczyk $\cdot$ D. C. C. Moebest $\cdot$ T. Zemojtel $\cdot$

M. Duchniewicz $\cdot$ M. P. Gantert $\cdot$ A. Dorn $\cdot$ D. Räpple $\cdot$

J. S. Scheele

Department of Medicine I,

University of Freiburg Medical Center,

Hugstetter Str. 55

79106 Freiburg, Germany

U. Hattenhorst $\cdot$ S. Burdach

Department of Pediatrics and Biocenter,

University of Halle,

Ernst-Grube-Str. 40,

06120 Halle (Saale), Germany

\section{P. Kamps}

Department of Pathology, University of California,

San Diego, School of Medicine,

9500 Gilman Drive,

La Jolla, CA 92093, USA

M. Kolanczyk

Department of Biology III, Institute for Biology,

University of Freiburg,

Schänzlestr. 1,

79104 Freiburg, Germany exon-6 and flanking intronic regions leading to exon 7 skipping in embryonic stem (ES) cells. We induced in vitro differentiation of wild-type and PBX1 mutant ES cells by aggregation and retinoic acid (RA) treatment and compared their profiles of gene expression at the ninth day post-reattachment to adhesive media. Our results indicate that PBX1 interactions with HOX proteins and DNA are dispensable for RA-induced ability of ES to express neural genes and point to a possible involvement of PBX1 in the regulation of imprinted genes.

T. Zemojtel

Department of Bioinformatics,

Max-Planck Institute for Molecular Genetics,

Ihnestrasse 63-73,

14195 Berlin, Germany

J. S. Scheele $(\bowtie)$

Department of Pharmacology I,

University of Freiburg Medical Center,

Albertstr. 25,

79106 Freiburg, Germany

e-mail: Juergen.scheele@uniklinik-freiburg.de

M. Kolanczyk · J. Hecht

Development and Disease Group,

Max-Planck-Institute for Molecular Genetics,

Ihnestrasse 63-73,

14195 Berlin, Germany

U. Lichtenauer $\cdot$ F. Beuschlein

Department of Medicine II,

University of Freiburg Medical Center,

Hugstetter Str. 55,

79106 Freiburg, Germany 
Keywords PBX1 $\cdot$ Differentiation $\cdot$ ES cells $\cdot$ Imprinting . Expression profiling

\section{Introduction}

PBX1 is a TALE (three amino acid loop extension) family non-HOX homeodomain transcription factor involved in the execution of multiple developmental programs of gene expression. PBX1 cooperatively binds DNA together with HOX proteins from paralogue groups $1-10$ as well as several transcription factors, e.g., Engrailed, Pdx1, and Prep/Meis (Chang et al. 1996; Lu and Kamps 1996; Peltenburg and Murre 1996; Shen et al. 1996, 1997; Knoepfler et al. 1997; Berthelsen et al. 1998; Goudet et al. 1999). Cooperative interactions of PBX1 and its partner proteins modify HOX protein DNA binding (Mann and Chan 1996). The functional importance of these interactions has been revealed by the observation that the PBX1 nullizygous embryos exhibit diffuse patterning defects restricted to the domains specified by Hox paralogues that bear the PBX dimerization motif (Selleri et al. 2001). On the side of PBX, interactions with HOX partners are facilitated by residues within the homeodomain and immediate carboxy-terminal to it (Chang et al. 1995; Lu and Kamps 1996; Piper et al. 1999). PBX-HOX complexes are thought either to positively or negatively regulate expression of target genes dependent on the context of cell signaling (Saleh et al. 2000b). In particular, activation of the protein kinase A pathway has been shown to switch PBX-HOX complexes from repressors to activators of transcription (Saleh et al. 2000a). Loss of PBX1 is associated with decreased cellular proliferation during development of bone, pancreas, blood, kidney, and the male genital ridge (DiMartino et al. 2001; Selleri et al. 2001; Kim et al. 2002; Schnabel et al. 2003a, b). However, it is not clear how PBX1 regulates early embryonic lineage commitment. To address this issue, we generated mouse embryonic stem cells bearing a homozygous deletion of exon- 6 of the $p b x 1$ gene, coding for the part of protein, which interacts with DNA and HOX proteins. Subsequently, both the wild-type (WT) and PBX1 mutant cells were differentiated in vitro using retinoic acid (RA) induction/aggregation methods, and gene expression profiles of their differentiated progeny were compared.

\section{Materials and Methods}

Vector design. The $\mathrm{PBX}^{\text {flox } 1}$ targeting vector was constructed by cloning of three adjacent PBX1 genomic fragments into pflox plasmid (Chui et al. 1997; Fig. 1a). The targeted sequence (subsequently referred to as the target) was composed of PBX1 exon-6 (1,192-1,356 bp in PBX1a AF020196 mRNA) flanked by 700 bp upstream and $280 \mathrm{bp}$ downstream intronic sequences (Fig. 1a).

Homologous recombination detection strategy. In the course of PBX ${ }^{\text {flox } 1}$ vector preparation, a HindIII restriction digest site was removed from the genomic sequence upstream of the targeted exon-6 (Fig. 1a). Removal of this restriction site by enzymatic digest and Klenow polymerase fill-in reaction allowed for Southern detection of homologous recombination events with the external Southern probe located upstream of the vector sequences (Fig. 1a,c).

Targeting of the first allele. The Not linearized PBX1 $1^{\text {flox } 1}$ plasmid was electroporated into the E14 embryonic stem (ES) cells followed by $6 \mathrm{~d}$ of G418 selection. The homologous recombination positive clones were identified using external Southern probe and two polymerase chain reaction (PCR) systems (Fig. 2; see online Electronic Supplementary Material for primer sequences).

$C R E$ recombination. Cells were electroporated with $20 \mu \mathrm{g}$ of CMV-Cre plasmid (a kind gift of Dr. Florian Otto) and serially diluted before plating. Colonies were picked and PCR-analyzed for the loss of target and selection cassette sequences (data not shown).

Targeting of the second allele. A single ES cell clone carrying a desired deletion of target and selection cassette sequence in the first copy of the gene (further referred to as $\triangle \mathrm{PBX}^{+/}$) was subjected to the second allele targeting with a modified PBX $1^{\text {flox } 2}$ vector (Fig. 1 b). In PBX1 $1^{\text {flox } 2}$ plasmid, target sequence was removed from between loxP sequences by BamHI digest and re-ligation (Fig. 1b). Due to this modification, integration of $\mathrm{PBX}{ }^{\text {flox } 2}$ into the second copy of the PBX1 gene causes direct exon- 6 ablation without the necessity of a subsequent round of CRE recombination (Fig. 1b).

ES cell culture. E14 ES cells were cultured in the presence of $1,000 \mathrm{U} / \mathrm{ml}$ of recombinant leukemia inhibitory factor (LIF; ESGRO, Chemicon International, Schwalbach, Germany) on the mitomycin (Sigma-Aldrich, Munich, Germany) treated CD-1.MTKneo2 embryonic fibroblasts according to standard procedures (Wasserman et al. 1993).

In vitro differentiation. The cells were differentiated according to the previously described aggregation/RA induction protocol (Bain et al. 1995; Gajovic et al. 1997) with two modifications:

1. Cell culture dishes were coated with $0.1 \%$ gelatin (Sigma) $/ 20 \mu \mathrm{g} / \mathrm{ml}$ laminin (Gibco/Invitrogen, Karlsruhe, Germany) prior to embryoid body (EB) reattachment. 


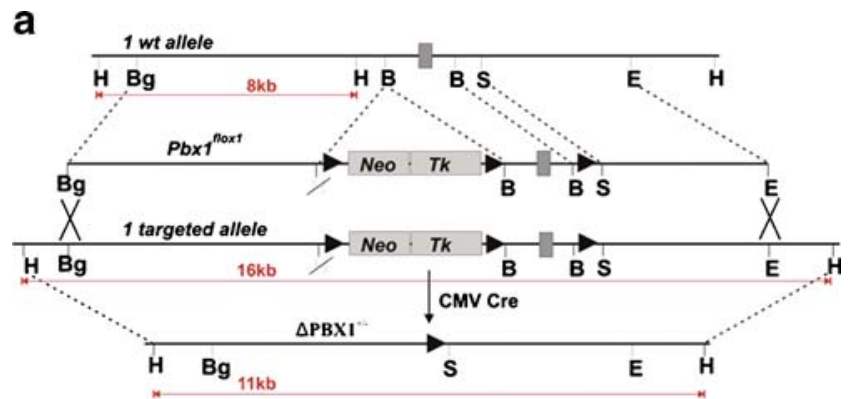

b

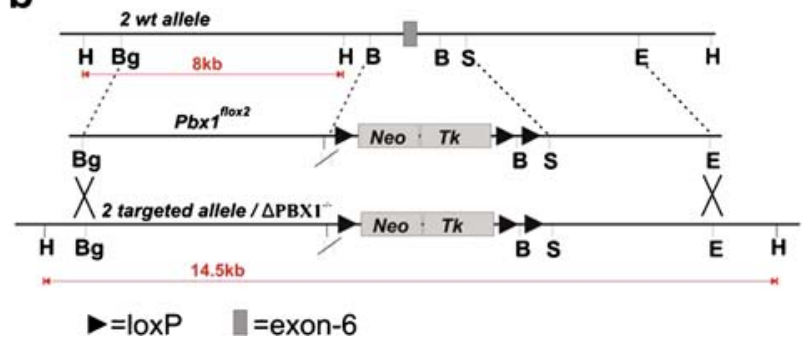

Figure 1. Schematic representation of the PBX1 locus modifications. (a) Schematic representation of the first allele targeting by homologous recombination and subsequent transient Cre recombinase expression. The targeting vector was based on the pFlox plasmid coding loxP flanked $P G K N e o / H S V-T K$ selection cassette. The first targeting vector contained a 1191-nucleotide fragment of PBX1 locus bearing exon- 6 flanked by loxP sequences. The HindIII site within the $5^{\prime}$ homology arm was removed from the targeting vector to allow homologous recombination detection by Southern blot. The 5' external probe used for the Southern blot analysis is shown as a solid black box above the mutated allele. $H$ HindIII, $N$ NotI, Bg BglII, B BamHI, E $E c o$ RI, $S$ SalI. As a result of the first homologous recombination and subsequent transient Cre expression, the sequence containing exon-6 as well as the selection cassette was removed from the first allele, yielding neomycin-sensitive $\triangle \mathrm{PBX}^{+/-}$ES cell clones. $(b)$ For the second targeting, the vector was modified by removing the target sequence containing exon- 6 with BamHI. The second round of homologous recombination yielded neomycin-resistant $\triangle \mathrm{PBX}^{-/-}$ clones.

2. The cells were allowed to differentiate for nine instead of $6 \mathrm{~d}$ after EB reattachment, in which time, media was exchanged daily.

Northern blot and real-time PCR. Total RNA was isolated from trypsinized cells using TriPure Isolation Reagent (Boehringer Mannheim, Mannheim, Germany). Reverse transcription was performed with TaqMan reverse transcription reagents (Applied Biosystems, Foster City, CA) and random hexamer primers according to supplied protocol. The reactions were done in $30-\mu$ l volumes using SYBR Green PCR master mix (Applied Biosystems) in the ABIPrism 7900HT cycler using primers listed in Fig. 3, Electronic Supplementary Material. Results were standardized to the level of GAPDH expression using a standard curve method according to Applied Biosystems guidelines. Northern blots were carried out as described previously
(Uchida et al. 1994). The reverse transcriptase PCR (RTPCR) derived probes specific for insulin growth factor-2 (IGF-2), insulin growth factor-2 receptor (IGF-2R), insulin growth factor-1 (IGF-1), insulin growth factor-1 receptor (IGF-2R), H19, Oct3/4, colipase and actin were labeled with $\left[-{ }^{32} \mathrm{P}\right] \mathrm{dCTP}(3,000 \mathrm{Ci} / \mathrm{mmol}$; Amersham Biosciences, Freiburg, Germany) using a Megaprime DNA labeling system (Amersham Biosciences).

Western blot. Whole cell lysates of differentiated cells were resolved by electrophoresis in $12 \%$ sodium dodecyl sulfate-polyacrylamide gels and transferred onto polyviny-
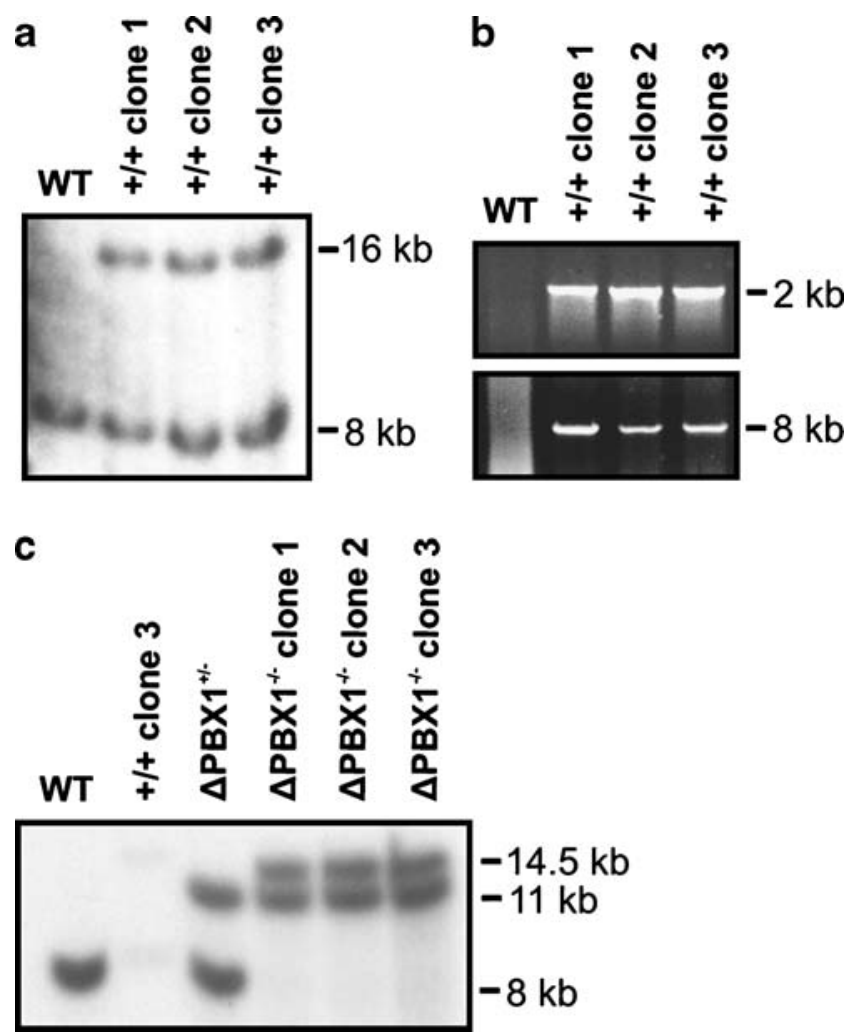

Figure 2. Detection of targeted genetic modification of the PBX1 locus. (a) Southern blot analysis of PBX1 clones after the first homologous recombination, before Cre treatment. DNAs of individual clones resistant to G418 were digested with HindIII and analyzed by Southern hybridization using a PCR-derived $5^{\prime}$ external southern probe (for primer sequences, see Electronic Supplementary Material). Shifts of WT 8 -kb bands to $16-\mathrm{kb}$ properly targeted allele bands were detected. (b) Confirmation of Southern blot analysis by long-range -8$\mathrm{kb}$ PCR and standard $-2-\mathrm{kb}$ PCR on the $5^{\prime}$ and $3^{\prime}$ homology arms of the vector. In both PCRs, one primer was based on the sequences external to the targeting vector and one inside the vector sequence. (c) Southern blot analysis of the clones after Cre recombination using a $5^{\prime}$ external hybridization probe. Cre recombinase catalyzed removal of the selection cassette together with the target sequence resulted in a decrease of the original $16-\mathrm{kb}$ band of the correctly targeted first allele to $11 \mathrm{~kb} \Delta \mathrm{PBX}^{+/-}$band (Fig. 1c). The second homologous recombination resulted in a shift of the 8-kb WT allele band to the $14.5-\mathrm{kb}$ correctly targeted second allele band. 


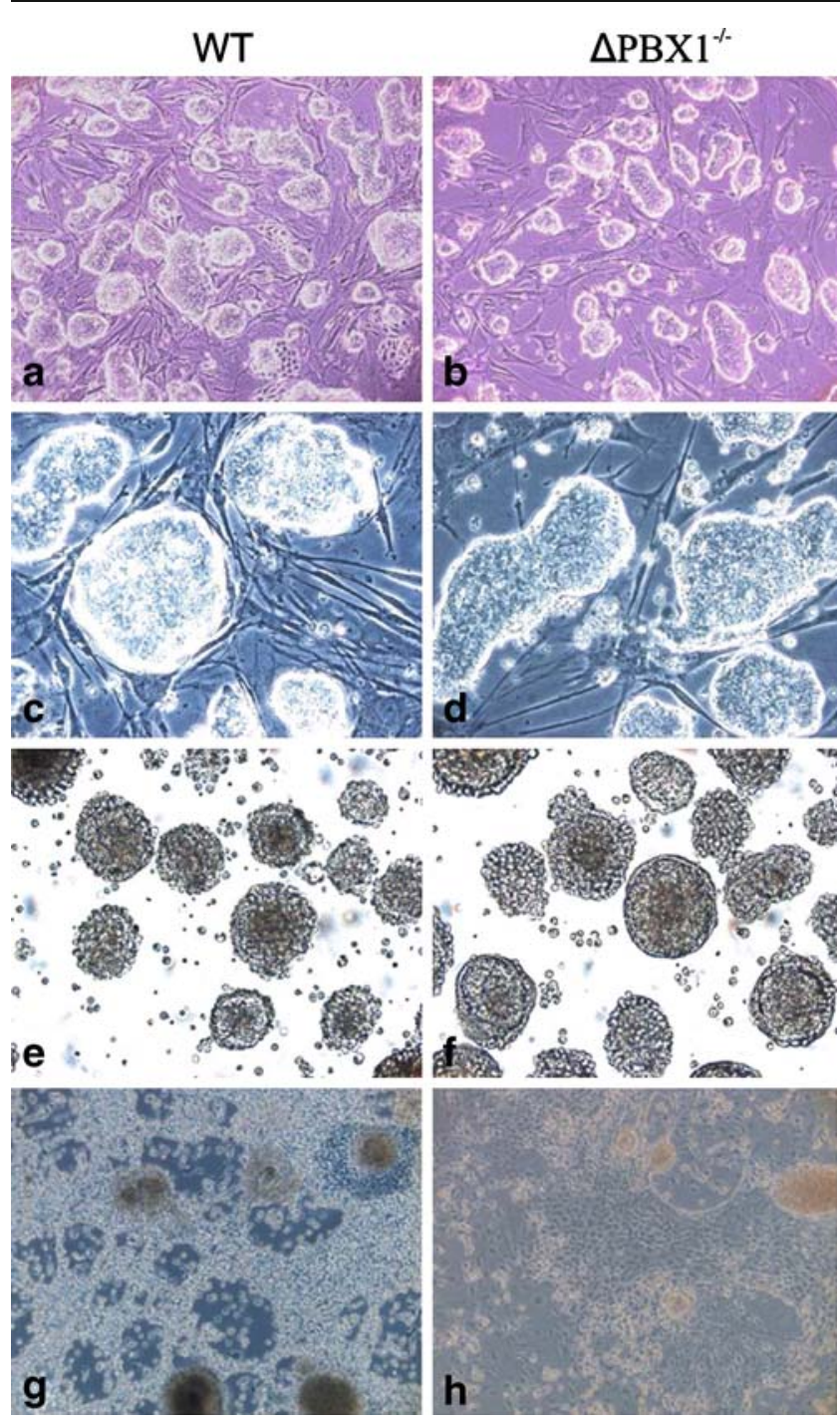

Figure 3. Morphology of the wild-type E14, mutant $\Delta \mathrm{PBX} 1^{+/-}$, and $\triangle \mathrm{PBX}^{-1-} \mathrm{ES}$ cells growing undifferentiated on the embryonic fibroblast and differentiating upon aggregation in the presence of RA. ( $a, b)$ Low-magnification digital images of the colonies of undifferentiated WT and $\Delta \mathrm{PBX}^{-/-}$embryonic stem cells. $(c, d)$ The same colonies photographed at higher magnification. WT and mutant cells grow in sharp-bordered colonies characteristic of undifferentiated ES cells. $(e, f)$ Embryoid bodies formed by each of the ES cell clones as a result of aggregation in non-adhesive dishes followed by RA induction. $(g, h)$ Morphology of differentiated ES cells $9 \mathrm{~d}$ after reattachment to the adhesive media. The $\Delta \mathrm{PBX}^{-/}$cells have a flattened appearance as they spread in the surroundings of the reattached aggregates.

lidene fluoride (Amersham) as described previously (Stock et al. 2003). PBX proteins were detected with PBX1/2/3 sc888 antibody (Santa Cruz, Heidelberg, Germany) and actin with sc-1615 antibody (Santa Cruz).

Immunostaining. Immunostaining of $\beta$-III-tubulin and ERK1 was performed as described previously using antibodies against beta-tubulin ( $\beta \mathrm{III})$ MMS-435P (BabCo,
Berkeley, CA) and ERK1 sc-94 (Santa Cruz; Bain et al. 1995).

Gene expression profiling using oligonucleotide microarray. Total RNA purified with the TriPure isolation reagent (Boehringer Mannheim) was repurified with RNeasy mini kit (Qiagen, Valencia, CA) and was used for experiments with Murine Genome U74A version 2 GeneChip arrays (Affymetrix, Santa Clara, CA), which contain probes for detecting 6,000 well-characterized genes and 6,000 expressed sequence tags. All labeling and hybridization steps were carried out according to Affymetrix protocols.

Data analysis using Affymetrix software. Scanned microarray images were analyzed with the Affymetrix microarray suite 4.0 software. The software identified differentially expressed transcripts by comparison of the differences in values of perfect match to mismatch of each probe pair in the baseline array (differentiated WT ES cells) to its matching probe pair on the experimental array (differentiated $\Delta \mathrm{PBX}^{-/-}$cells). The signal log ratios calculated for each transcript were converted into fold change using Affymetrix recommended formula. The results of comparison of the WT and two PBX1 mutant clones were cross-compared, and 117 transcripts were consistently deregulated in both mutant clones selected (see Electronic Supplementary Material).

\section{Results}

First allele targeting. The linearized $\mathrm{PBX} 1^{\text {flox } 1}$ construct (Fig. 1a) was electroporated into a 129/Ola background E14 ES cell line and cultured on the embryonic fibroblast feeder layers, in the presence of LIF, according to standard protocol (Wasserman et al. 1993). This strategy was chosen to create both ES cells for differentiation and generate transgenic knockout mice with the same approach. Following positive selection in G418, homologous recombinant clones were identified by Southern blot analysis using HindIII digest and the $5^{\prime}$ external Southern blot probe (Fig. 2a). This probe hybridizes to the 8-kb fragment of the wild-type allele and the 16-kb fragment of a correctly targeted allele (Fig. 2a). The homologous recombination events, detected by Southern blot, were confirmed by PCR amplification of the $5^{\prime}$ and $3^{\prime}$ ends of the targeting vector, with one primer based on the sequence inside and one external to the vector sequence (Fig. 2b).

CRE recombination. Two homologous recombination positive clones were expanded and electroporated with $20 \mu \mathrm{g}$ of CMV-Cre expression vector (kind gift of Dr. Florian 
Otto). In the next step, two recombinant clones with the excised selection cassette and exon- 6 sequences were selected in a PCR-based screen from each of the ES cell sub-lines (data not shown).

Second allele targeting. A single clone of Cre-treated cells, from which both the target sequence containing exon- 6 and flanking intronic regions (700 bp upstream and $280 \mathrm{bp}$ downstream from exon-6) of PBX1 and the selection cassette had been removed, was subjected to a second gene copy targeting procedure (Fig. 1b). The targeted sequence was removed from the $\mathrm{PBX}^{\text {flox } 1}$ vector through $\mathrm{BamHI}$ digest and re-ligation. This $\mathrm{PBX} 1^{\text {flox } 2}$ plasmid allowed for direct inactivation of the second copy of the PBX1 gene (Fig. 1b). Recombinants were selected in G418 and screened using the same $5^{\prime}$ external Southern probe as in the first allele targeting. A shift of the $8 \mathrm{~kb}$ WT band to the properly targeted, $14.5 \mathrm{~kb}$, second allele band was detected (Fig. 2c). The effect of targeting both alleles was assessed at the mRNA and protein expression level in the differentiated $\triangle \mathrm{PBX}^{-/-}$cells (see following subsection).

In vitro ES cells differentiation. The $\triangle \mathrm{PBX}^{-/-}$cells, cultured on mitomycin-C-pretreated embryonic fibroblasts in the standard medium supplemented with LIF, retained morphological features of undifferentiated ES cells. Furthermore, all analyzed sub-lines expressed the Oct3/4 gene, indicating their undifferentiated state (Fig. 6). Aggregation in the media supplemented with $1 \%$ fetal calf serum and RA was employed in order to induce neuro-ectodermal differentiation, as described in "Materials and Methods". WT and $\triangle \mathrm{PBX}^{-/-}$cells cultured in the non-adhesive bacterial grade dishes formed embryoid bodies (Fig. 3e-f), which, stimulated by RA, differentiated into morphologically distinguishable cell types (Fig. $3 g-h$ ). Wild-type cells grew densely and acquired predominantly bead-like forms structured into grainy nests (Fig. $3 g$ ). On the contrary, most of the differentiated $\triangle \mathrm{PBX}^{+/-}$and $\triangle \mathrm{PBX}^{-/-}$cells had a flat morphology, resembling mesenchymal cells (Fig. $3 h$ ).

Targeted deletion of exon-6 and flanking intronic regions results in the expression of $\triangle(280-370) P B X 1$ mutant protein. In order to determine the effect of targeting both alleles on mRNA and protein expression, we performed RTPCR, real-time PCR, and Western blot analysis of differentiated cells. As expected, in the RT-PCR where one of the primers was designed to recognize $\mathrm{PBX} 1$ exon- 6 region, no product could be detected in the $\triangle \mathrm{PBX}^{-/-}$cells (Fig. $1 a$, Electronic Supplementary Material).

Reactions with primers designed to amplify the coding sequence of PBX1 resulted in a single band corresponding to mutant cDNA (Fig. 1b, Electronic Supplementary Material). Subsequent cloning and sequencing of the transcript revealed lack of the sequences encoded by exon- 6 and exon- 7 . Observed exon-7 skipping and loss of alternative splicing of exon-8 resulted from deletion of intronic splicing regulatory sequences (Fig. 2, Electronic Supplementary Material).

Since the lack of the exon- 6 and exon-7 sequences does not result in a frame shift, the mutant cDNA encodes a protein lacking amino acids $280-370$, termed here $\Delta(280$ 370)PBX1 (for the cDNA evidence, see Fig. 2 of Electronic Supplementary Material). The C-terminal 70 AA remains in the $\triangle$ PPBX1 translated protein. Since the antibody we used is directed against the $\mathrm{C}$ terminus of all three paralogues, PBX1/2/3, in Western blot, we detected expression of the $\Delta(280-370) \mathrm{PBX} 1$ mutant protein in $\Delta \mathrm{PBX}^{+/-}$and $\triangle \mathrm{PBX}^{-/-}$cells (Fig. 4).

Interestingly, Western blot revealed a large amount of full-length $\mathrm{PBX} 1 / 2 / 3$ protein (band above the $49-\mathrm{kDa}$ marker) detected by the PBX1/2/3 antibody. In order to further explain this observation, we quantified PBX2 and

a

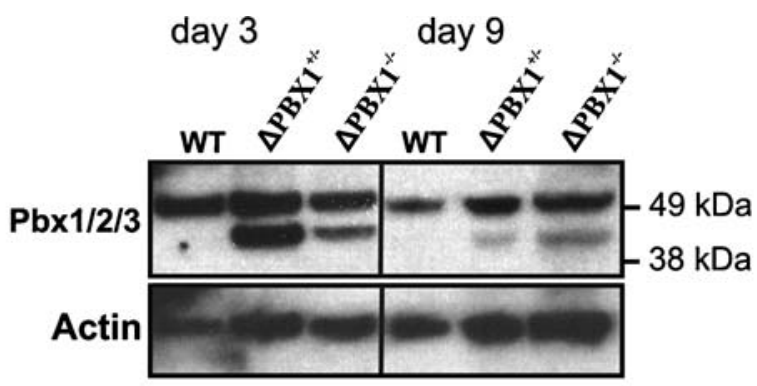

b
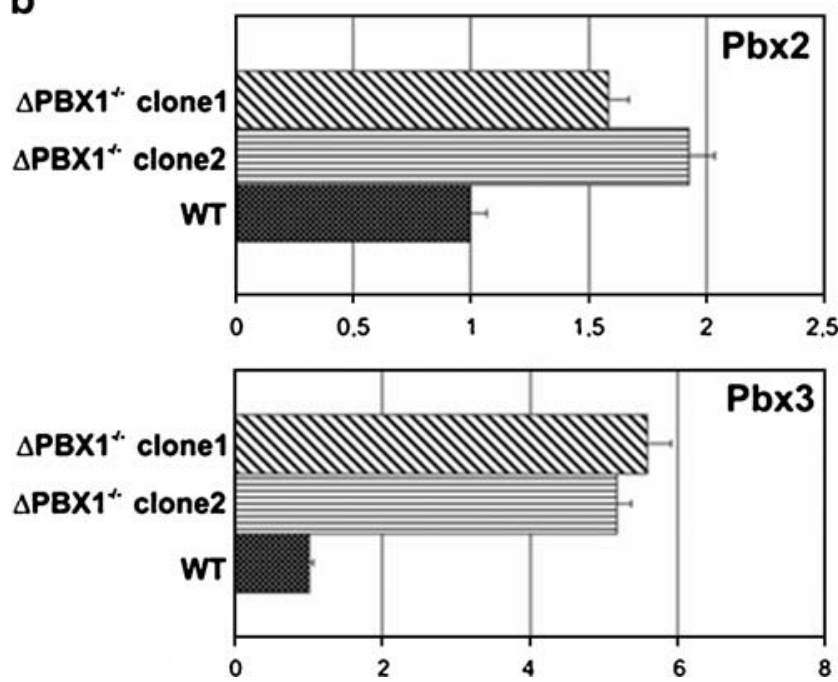

Figure 4. Analysis of PBX protein and mRNA expression. (a) Western blot analysis of $\mathrm{PBX} 1 / 2 / 3$ expression in the differentiated $\mathrm{WT}, \triangle \mathrm{PBX}^{+/-}$, and $\triangle \mathrm{PBX} 1^{-1-}$ cells on the ninth day after reattachment to adhesive cell culture dishes. Immunodetection of actin served as the loading control and was carried out on the same blots following PBX antibody striping. (b) Real-time PCR quantification of PBX2 and PBX3 transcripts in differentiated WT cells and two $\triangle \mathrm{PBX} 1^{--}$clones on the ninth day after reattachment to adhesive cell culture dishes. 
PBX3 transcripts in mutant cells. Their expression was upregulated almost twofold and more than 5-fold in $\triangle \mathrm{PBX}^{-1-}$ cells compared with WT cells, respectively. Therefore, a high level of WT PBX protein expression in the differentiated $\triangle \mathrm{PBX} 1^{-/-}$cells correlates with relative abundance of PBX3 transcripts (Fig. 4). See "Discussion" for further comments on this observation.

Comparative genome wide expression profiles of differentiated WTand $\triangle P B X 1^{-/}$cell lines. Total RNA from differentiated, RA-induced, day 9 post-attachment WT and $\triangle \mathrm{PBX}^{-/-}$cell populations (one clone of wild-type cell and two clones of $\triangle \mathrm{PBX}^{-1-}$ cells) was hybridized to the Affymetrix $\mathrm{Mu}$ _U94Av2 microarray. A total of 680 genes for the first $\triangle \mathrm{PBX} 1^{-/-}$clone and 473 genes for the second $\triangle \mathrm{PBX} 1^{-/-}$ clone were differentially expressed (two-fold or more difference) in comparison to the WT cells. Out of those, 117

a

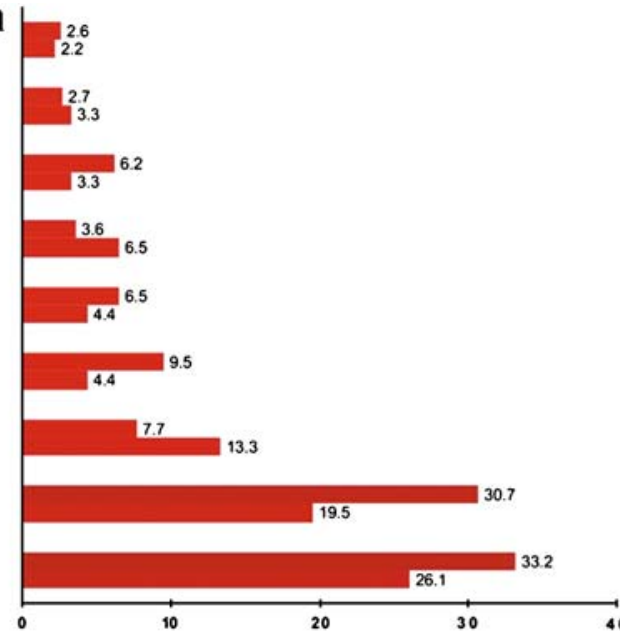

b

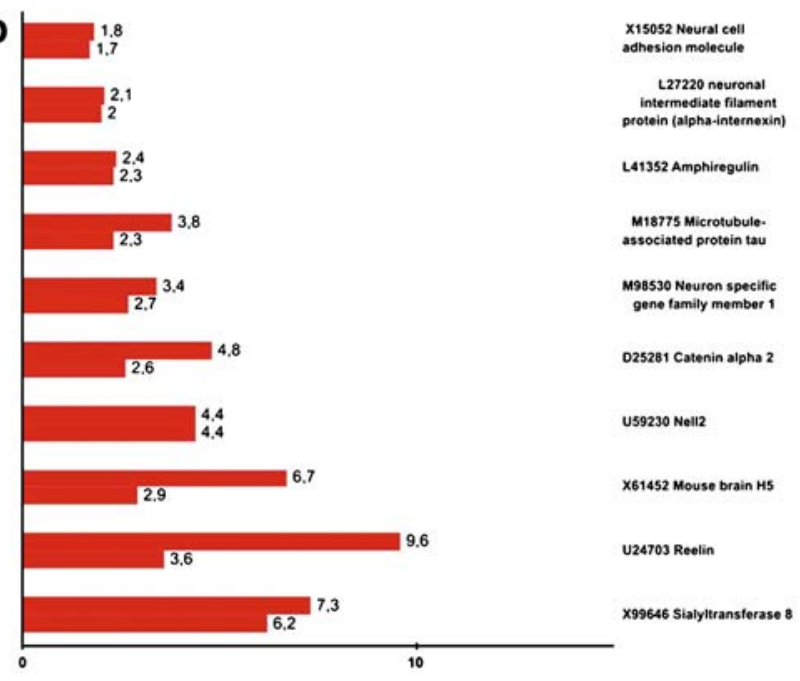

Figure 5. The microarray-based comparative gene expression profiling of differentiated $\triangle \mathrm{PBX}^{-/-}$and WT cells. Represented are regulations consistently observed in two clones of $\triangle \mathrm{PBX} 1^{-/}$cells. AA839903 myosin ligh Af 041847 cardiac ankyrin X 12972 M urine MLC NV M 15501 A ctin, alpha.

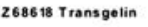
AJ223362 slow myosin
heavy chain-beta 13297 vascular smooth muscle alpha-actin M) 12347 Actin, alpha 1 .
skeletal muscle (1) commonly regulated genes were identified in both analyzed clones.

A selection of the 117 gene regulations is presented in Fig. 5 and the complete list is accessible at Tables 1, 2, and 3 of Electronic Supplementary Material (MS Excel ${ }^{\circledR}$ format available).

Differentiated $\triangle P B X 1^{-/}$cells exhibit intensified expression of neural and muscle specific genes. Nine muscle (Fig. 5b) and ten neuron (Fig. $5 a$ ) specific genes were consistently upregulated in both clones of $\triangle \mathrm{PBX} 1^{-/-}$cells. Among those, expression of striated smooth and cardiac-musclespecific actin isoforms indicated that the $\triangle \mathrm{PBX} 1^{-/-}$cells had acquired a muscle phenotype.

Interestingly, expression of reelin, a gene known to play an important role both in brain development and neuromuscular junction formation, was upregulated in both

\section{C} tight chain
lor myos in alkall

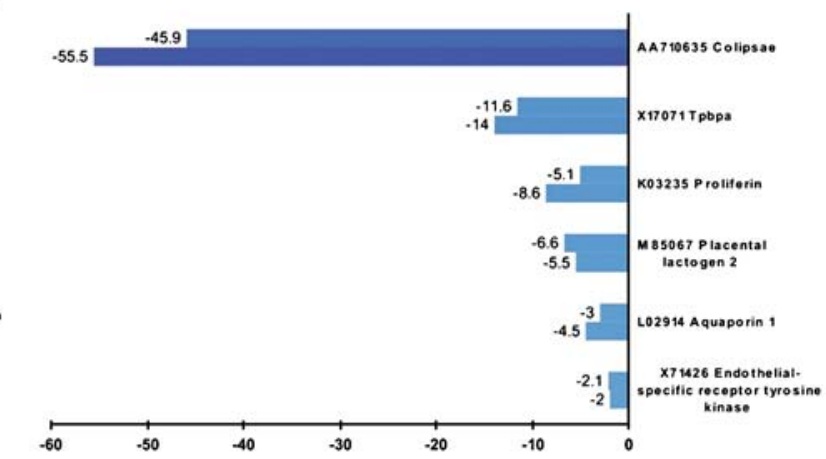

d

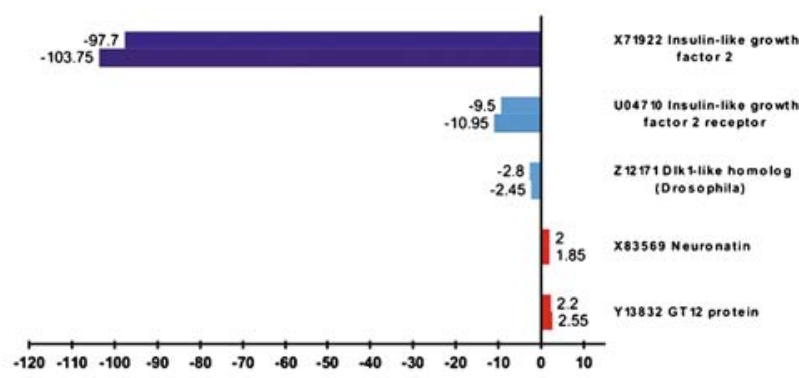

Upper and lower bars represent values of gene deregulation in $\triangle \mathrm{PBX}^{-1-}$ clone- 1 and $\triangle \mathrm{PBX} 1^{-1-}$ clone- 2 , respectively, as compared to the WT cells. Fold change values are depicted next to the bars. 
Figure 6. Differentiated $\triangle \mathrm{PBX} 1^{+/-}$and $\triangle \mathrm{PBX}^{-/-}$cells do not express IGF2, IGF2R, and colipase genes. Total RNA (15 $\mu \mathrm{g} / \mathrm{lane})$ isolated from undifferentiated $(0)$ and differentiated (9) WT, $\triangle \mathrm{PBX}^{+/}$, and $\triangle \mathrm{PBX}^{-/-}$embryonic stem cells was used in the Northern blot as described in "Materials and Methods". Genotypes and stages of differentiation are assigned above the panel: $(0)=$ undifferentiated, $(9)=$ ninth day post-attachment of embryoid bodies to adhesive culture dishes. Efficiency of blotting was controlled by staining RNA on the membrane with ethidium bromide (top of the panel).

differentiated $\Delta \mathrm{PBX}^{-/-}$clones (Quattrocchi et al. 2003). Expression of two EGF-related growth factors, amphiregulin (L41352) and NELL2 (U59230), reported to function as potent mitogens for the neural stem cells in vitro (Falk and Frisen 2002; Aihara et al. 2003) was also increased. Other neural genes, upregulated in differentiated $\triangle \mathrm{PBX}^{-/}$cells, play roles in such processes as:

(a) Cell adhesion: catenin alpha-2 (D25281; Uchida et al. 1994), sialyltransferase-8 (X99646; Kojima et al. 1995a, b) and

(b) Cytoskeleton regulation: neuronal intermediate filament protein (L27220), microtubule-associated protein tau (M18775; Lee et al. 1988), mouse brain H5 (X61452; Kato 1992).

A slight increase of N-CAM and 3.7-fold increase of GFAP expression was observed (Table 1, Electronic Supplementary Material).

Not only the neuron-specific genes but also genes for skeletal muscle like alpha1-actin, for cardiac muscle like myosin-heavy polypeptide 7 , and for smooth muscles like h2-calponin were upregulated (Table 3, Electronic Supplementary Material)

Decreased expression of trophectoderm and endothelial marker genes. In addition, we detected pronounced differences in trophectodermal marker gene expression between differentiated WT and $\triangle \mathrm{PBX}^{-/-}$cells. Expression of spongiotrophoblast-specific gene Tpbpa (X17071; Lescisin et al. 1988), trophoblast giant-cell-specific placental lactogen-II (M85067), and proliferin (K03235; Adamson et al. 2002) were downregulated (Fig. 5c). Similarly, genes demarcating epithelial cells derived from endoderm and mesoderm, e.g., vascular-specific endothelial-specific receptor tyrosine kinase (X71426) were downregulated (Fig. 5c; Sato et al. 1993).

Aquaporin1/CHIP28 (L02914), which is expressed predominantly in endothelium of kidney, lung, trachea, and heart, but also in placental syncytial trophoblast cells (Hasegawa et al. 1994), and colipase (AA710635), expressed in pancreas, stomach, and colon (D'Agostino et al. 2002), also showed decreased expression. Since colipase exhibited the strongest downregulation within this group of genes, we have further confirmed its deregulation in

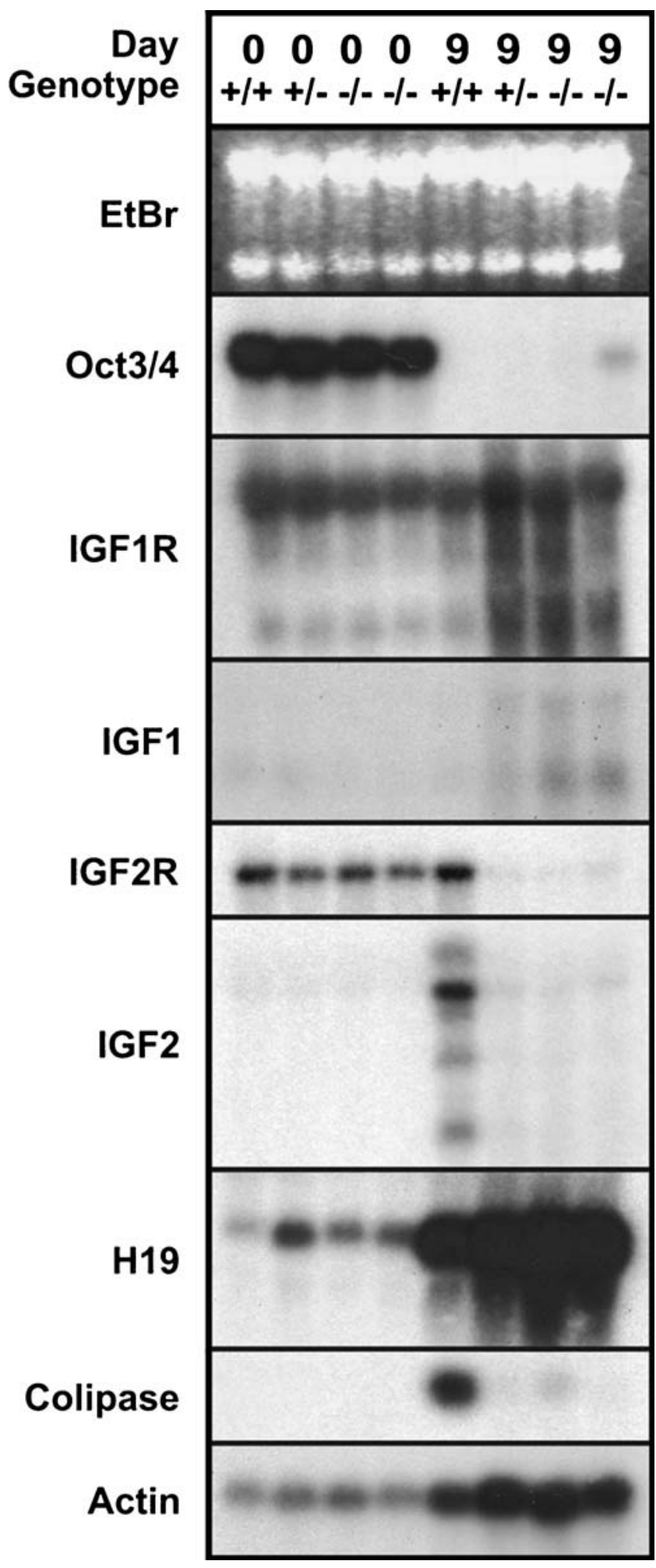

Northern blot, which revealed that whereas expression of colipase was strongly induced during WT ES cells differentiation, it remained silent in $\triangle \mathrm{PBX}^{+/-}$and $\triangle \mathrm{PBX}^{-/-}$cells (Fig. 6). Furthermore, deregulations of 

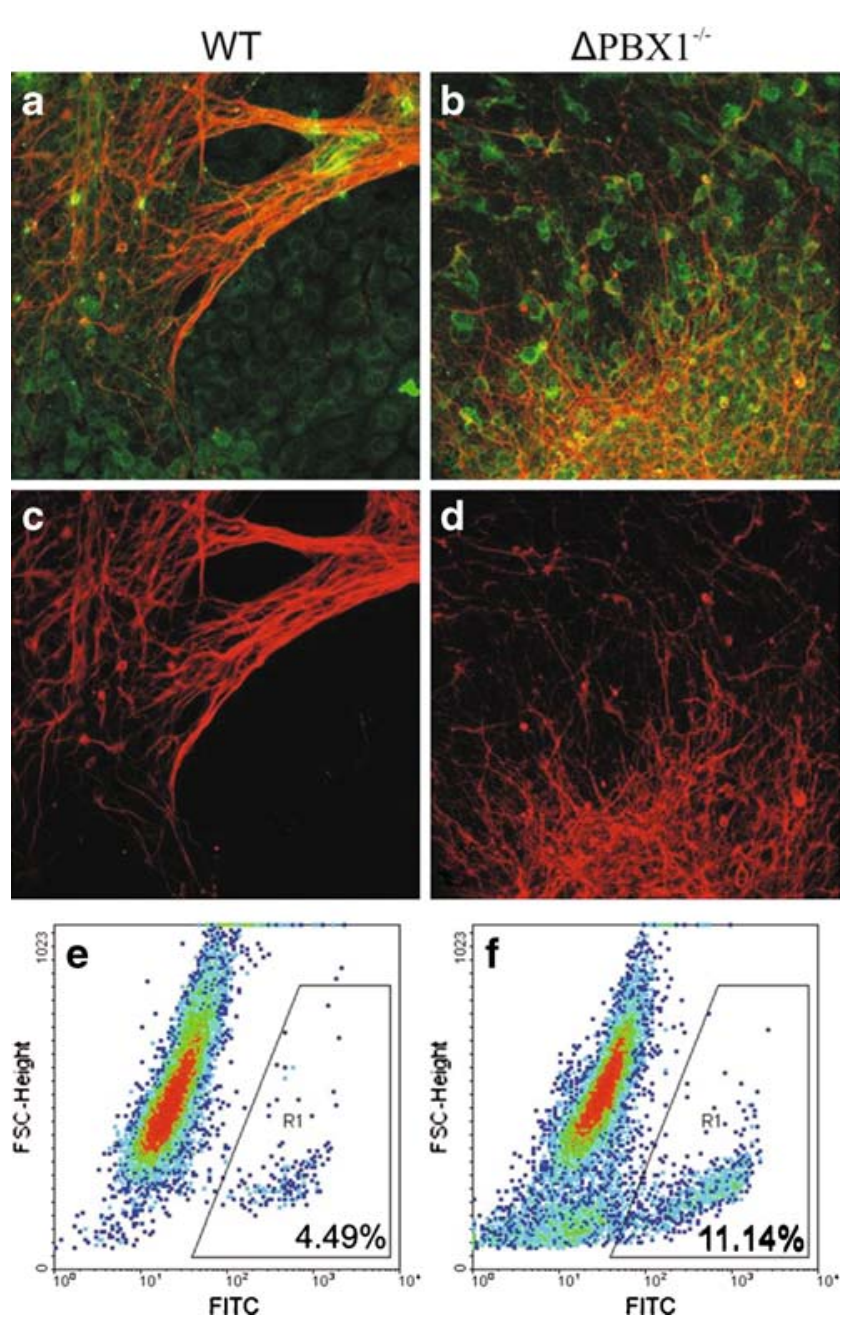

Figure 7. RA-treated $\triangle \mathrm{PBX} 1^{-/-} \mathrm{ES}$ cells differentiate into neurons. $(a, b)$ Confocal microscopy images of differentiated WT and $\triangle \mathrm{PBX}^{-/-}$embryonic stem cells on the ninth day post-reattachment of embryoid bodies to adhesive media. $(c, d)$ Expression of neuronspecific class III beta-tubulin (red) and extracellular signal-regulated kinases 1 (ERK1, green) were visualized by indirect immunofluorescence. A beta-III-tubilin composite of the same images. $(e, f)$ FACSbased quantification of the beta-III-tubulin-stained, neural cell populations derived in WT $(e)$ and $\Delta \mathrm{PBX}^{-/-}(f)$ cell cultures.

aquaporin1/CHIP28 (L02914) and endothelial-specific receptor tyrosine kinase (X71426) were confirmed by realtime PCR (Fig. 3, Electronic Supplementary Material).

Deregulation of imprinted genes: IGF2, IGF2R, H19, DLK1, GTL-1, and neuronatin. Interestingly, the microarray experiments resulted in the discovery of the striking downregulation of insulin growth factor 2 (X71922) as well as its receptor (U04710) in $\Delta \mathrm{PBX}^{-/-}$cells (Fig. $5 d$ ).

Consistently, Northern blot analysis revealed that IGF2 was expressed only in differentiated wild-type cells (Fig. 6). The IGF2 receptor was expressed in all undifferentiated cells and differentiated WT cells, whereas in differentiated $\Delta \mathrm{PBX}^{+/-}$and $\triangle \mathrm{PBX}^{-/-}$cells, its expression was barely detectable. This IGF2 deregulation prompted us to check the expression of another imprinted gene, H19, known to share common regulatory sequences with IGF2 (Srivastava et al. 2000). Northern blot revealed $H 19$ expression to be intensified in $\triangle \mathrm{PBX}^{+/-}$and both $\triangle \mathrm{PBX} 1^{-/-}$cells (Fig. 6).

Similarly, H19, IGF1, and IGF1R were also slightly upregulated in the differentiated knockout cells (Fig. 6). Interestingly, three other imprinted genes, GTL-2 (Y13832), DLK-1 (Z12171), and neuronatin (X83569), were also deregulated (Fig. 5c). GTL-2, like H19, is expressed from the maternal allele (Schmidt et al. 2000; Takada et al. 2000). Its expression was induced in the differentiated $\triangle \mathrm{PBX}^{--}$cells. The paternally expressed $D L K-1$ gene encodes a homologue of the Notch-Delta family of developmental regulated signaling molecules (Laborda 2000 ) and is co-regulated with GTL-2. Its expression was silenced in the $\triangle \mathrm{PBX}^{-/-}$clones (Fig. $5 c$ ). Expression of neuronatin (NNAT) was induced in mutant cells. The gene is normally transcribed from the unmethylated paternal allele in neural tissue and CD34-positive blood cell progenitors (Kuerbitz et al. 2002). Deregulation of imprinted genes was further confirmed by Northern blot (Fig. 6) or real-time PCR (Fig. 3, Electronic Supplementary Material).

Expansion of neural cell lineage in differentiating $\triangle P B X 1^{-/-} E S$ cells. The presence of neurons in the populations of differentiated WT and $\triangle \mathrm{PBX}^{-/-}$cells was confirmed by cytoimmunochemical staining with antibody against a post-mitotic neural marker beta-IIItubulin (Tuj1; Mann and Chan 1996). We observed outgrowths of neural processes in the surroundings of differentiated aggregates of both WT and PBX1 mutant cells; it was, however, most pronounced in the mutant cell cultures (Fig. $7 a-d$ ). Subsequently, the neural cell populations were quantified by fluorescence-activated cell sorting (FACS) of anti- $\beta$-III-tubulin-stained cells (Fig. 7e,f). A marked increase $(\sim 5 \%)$ in Tuj1-positive cell numbers was detected in cultures of differentiated $\Delta \mathrm{PBX}^{-/-}$cells as compared with WT cells.

Supplemental information online. The relative fold change values of gene expression are stored in the Excel file format and can be accessed at http://www.uniklinik-freiburg.de/ medizin1/live/permalink/scheele2009.html.

\section{Discussion}

Overview of the experimental model. Utilizing the CreloxP system, we targeted a functionally important part of the homeodomain of PBX1 in ES cells. Genomic modifi- 
cation resulted in expression of the $\Delta(280-370)$ PBX1 mutant protein (Fig. 4.). Multiple in vitro experiments and structural data have indicated that the 280-370 a.a. region facilitates both PBX1-HOX and PBX1-DNA interactions (Lu and Kamps 1996; Peltenburg and Murre 1997; Jabet et al. 1999; Piper et al. 1999; LaRonde-LeBlanc and Wolberger 2003).

By employing DNA microarray technology, we compared transcriptional profiles of in vitro differentiated WT and $\triangle \mathrm{PBX}^{-/-} \mathrm{ES}$ cells. In the following subsections, we discuss functional aspects of the identified gene regulations.

$\triangle P B X 1^{-/-}$ES cells express neural genes. Cell aggregation and RA treatment in media with low serum content are known to lead to efficient neuroectodermal differentiation of ES cells. In the process of differentiation, various genes are expressed in a specific temporal order. Some of them are expressed by undifferentiated ES cells (OCT4, BMP4; Niwa et al. 2000; Ying et al. 2003) and others are upregulated during early differentiation (PAX6, Nestin, OTX1; Okabe et al. 1996; Gajovic et al. 1997), still others during late differentiation ( $\beta$-III-tubulin, GFAP, N-CAM; Bain et al. 1995; Fraichard et al. 1995). Varieties of genes active in this process were revealed by a recent survey of the ES cells to neural lineage differentiation transcriptome (Ahn et al. 2004).

In the current study, we compared transcriptomes of WT and $\triangle \mathrm{PBX}^{-1-}$ mutant cells. Our results indicate that $\triangle \mathrm{PBX}^{--}$mutant cells not only retain the capability to express neural genes in response to RA treatment but also express them at higher levels as compared with WT cells. Consistently, FACS analysis revealed relative expansion of $\beta$-III-tubulin-expressing cell population, correlating with widespread outgrowth of neural processes in cultures of differentiated PBX1 mutant cells (Fig. 7a-d). We conclude that a greater proportion of $\triangle \mathrm{PBX} 1^{-/}$mutant cells undergo neural differentiation as compared to WT cells. We hypothesize that the relative abundance of PBX3 transcripts in populations of differentiated $\triangle \mathrm{PBX}^{-/}$cells is a direct result of neural population expansion. Transcripts of PBX3 were recently found to be upregulated in the ES cells differentiating to midbrain and hindbrain neurons (Ahn et al. 2004). Consistently, PBX3 expression in the mid-gestation mouse embryo is restricted to the central nervous system; PBX3deficient mice have been shown to die from central respiratory failure due to abnormal activity of inspiratory neurons in the medulla (Rhee et al. 2004). Furthermore, Knoepfler and Kamps (1997) have shown that retinoic acid upregulates PBX protein abundance coincident with transcriptional activation of Hox genes in P19 embryonal carcinoma cell undergoing neuronal differentiation. Using an approach different from double-allele knockout, other investigators applied SI-RNA technique to eliminate expression of PBX1 and the related PBX2 and PBX3 genes. They could show that
PBX proteins are required for RA-induced differentiation of P19 cells (Qin et al. 2004). Not only in transformed cell lines but also in the rat model did the expression of PBX1 in the subventricular zone precursor cells suggest a role of PBX1 in mammalian neurogenesis (Redmond et al. 1996).

Deregulation of myogenic, endothelial, and trophectodermal genes. In addition, genetic markers of other cell lineages were found to be deregulated. Intensified expression of muscle-specific genes (Fig. 5b) accompanied that of neural markers. Based on our microarray data, we can hypothesize that mutant cells differentiate into two predominant neural and muscle cell lineages. Alternatively, expression of both neural and muscle-specific genes could be attributed to expansion of the common neuromuscular progenitor cell population.

Mouse ES cells, although derived from the epiblast (Brook and Gardner 1997), which, during gastrulation, does not contribute to the trophectodermal lineage (Beddington and Robertson 1989), are capable of acquiring trophectodermal phenotypes upon withdrawal of LIF (Niwa et al. 2000). Our results are in agreement with this observation, as the high levels of trophectodermal marker gene expression were detected in differentiated WT ES cells. However, differentiated $\triangle \mathrm{PBX}^{-/-}$cells exhibited decreased expression of trophectoderm markers as well as endoderm-derived epithelial genes, suggesting involvement of PBX1 in the molecular program leading to commitment into those lineages (Fig. $5 c$ ).

Deregulation of imprinted genes in $\triangle P B X 1^{-/}$cells. Interestingly, the microarray experiment resulted in the discovery of very strong downregulation of $I G F 2$ and $I G F 2 r$ genes in the knockout cells. Whereas in WT cells IGF2 and $I G F 2 r$ expression were strongly induced during differentiation, it remained uninduced in differentiating mutant cells. Loss of expression of these genes in $\triangle \mathrm{PBX}^{+/-}$and $\triangle \mathrm{PBX}^{-1-}$ cells could be explained either by their inability to differentiate into $I G F 2$ - and $I G F 2 r$-expressing cell populations or by loss of PBX1-mediated transcriptional regulation. A strong argument against the hypothesis of the cell population shift as a major reason for the loss of IGF2 expression is delivered by the coordinate upregulation of the $\mathrm{H} 19$ gene. It has been shown that expression of these two genes in endoderm and mesoderm relies on a common set of enhancers and is almost identical spatially and temporarily (Leighton et al. 1995). Interestingly, deregulation of $I G F 2, I G F 2 r$, and $H 19$ genes in PBX1 $\triangle 280-370$ mutant expressing cells resembles the situation in the DNAmethyltransferase-defficient (DNMT-1) knockout embryos where transcription of $I G F 2$ and its receptor is completely abolished and the normally inactive paternal copy of H19 gene becomes activated ( $\mathrm{Li}$ et al. 1993). Additionally, two other imprinted genes, GTL-2 and neuronatin, were also 
found to be deregulated in $\triangle \mathrm{PBX} 1^{-/-}$cells (Takada et al. 2002; Lin et al. 2003). Expression of all these genes is crucially dependent on DNA methylation ( $\mathrm{Li}$ et al. 1993, 2003). It is therefore tempting to speculate that PBX1 has a function in establishing their methylation patterns.

\section{Conclusions}

In conclusion, our experimental model yielded the discovery of a variety of new genes whose expression is associated with PBX1 function. Identification of possible links between their deregulations and the phenotype of previously described PBX1 knockout mice awaits future investigation. The loss of IGF2 expression in differentiated $\triangle \mathrm{PBX}^{-/-}$ cells is especially interesting in the context of decreased cellular proliferation rate in developing bone, pancreas, the hematopioetic system, kidney, and the male genital ridge of PBX1 knockout mice (DiMartino et al. 2001; Schnabel et al. 2001, 2003a, b; Selleri et al. 2001; Kim et al. 2002). Development of most of these organs has been previously linked to the mitogenic function of IGF2 (Van Wyk and Smith 1999; Zumkeller and Burdach 1999; Kido et al. 2002; Kim et al. 2002). In particular, the roles of PBX1 and $I G F 2$ are well recognized in normal pancreas development (Kido et al. 2002; Kim et al. 2002). Several studies have demonstrated that exocrine pancreatic development is crucially dependent upon mesenchymal/epithelial interactions, suggesting that exocrine growth factors play an essential role in this process (Jonsson et al. 1994; Sanvito et al. 1994; Gittes et al. 1996; Rose et al. 1999). Additionally, formation of acinary cell structures in vitro could be rescued in $\mathrm{PBX}^{-1-}$ explants by WT mesoderm tissue in recombination experiments (Kim et al. 2002). However, PBX1-regulated mesodermal growth factors, capable of rescuing exocrine pancreatic cell differentiation, were not identified.

Our data open a new possibility whereby PBX1 influences embryonic growth as well as endoderm and trophectoderm differentiation through regulation of the imprinted genes $I G F 2$ and $I G F 2 r$.

Furthermore, we establish that PBX1 interactions with HOX and DNA are dispensable for neural gene expression. The last is interesting in the light of a recent report on the permissive role of $\mathrm{PBX}$ proteins in RA-induced neural differentiation of $P 19$ carcinoma cell line (Qin et al. 2004). Still, the possible involvement of the PBX1 N-terminal domain in neural commitment remains to be tested.

Acknowledgments This work was supported by Deutsche Forschungsgemeinschaft Grant Sche 354-3.1. We thank Dr. Martin Trepel for useful discussions and Dr. Marie Follo for help with confocal microscopy.

\section{References}

Adamson S. L.; Lu Y.; Whiteley K. J.; Holmyard D.; Hemberger M.; Pfarrer C.; Cross J. C. Interactions between trophoblast cells and the maternal and fetal circulation in the mouse placenta. Dev. Biol. 250: 358-373; 2002.

Ahn J. I.; Lee K. H.; Shin D. M.; Shim J. W.; Lee J. S.; Chang S. Y; Lee Y. S.; Brownstein M. J.; Lee S. H. Comprehensive transcriptome analysis of differentiation of embryonic stem cells into midbrain and hindbrain neurons. Dev. Biol. 265: 491-501; 2004. doi:10.1016/j.ydbio.2003.09.041.

Aihara K.; Kuroda S.; Kanayama N.; Matsuyama S.; Tanizawa K.; Horie M. A neuron-specific EGF family protein, NELL2, promotes survival of neurons through mitogen-activated protein kinases. Brain Res. Mol. Brain Res. 116: 86-93; 2003. doi:10.1016/S0169-328X(03)00256-0.

Bain G.; Kitchens D.; Yao M.; Huettner J. E.; Gottlieb D. I. Embryonic stem cells express neuronal properties in vitro. Dev. Biol. 168: 342-357; 1995. doi:10.1006/dbio.1995.1085.

Beddington R. S.; Robertson E. J. An assessment of the developmental potential of embryonic stem cells in the midgestation mouse embryo. Development 105: 733-737; 1989.

Berthelsen J.; Zappavigna V.; Mavilio F.; Blasi F. Prep1, a novel functional partner of $\mathrm{Pbx}$ proteins. Embo J. 17: 1423-1433; 1998. doi:10.1093/emboj/17.5.1423.

Brook F. A.; Gardner R. L. The origin and efficient derivation of embryonic stem cells in the mouse. Proc. Natl. Acad. Sci. U. S. A. 94: 5709-5712; 1997. doi:10.1073/pnas.94.11.5709.

Chang C. P.; Brocchieri L.; Shen W. F.; Largman C.; Cleary M. L. Pbx modulation of Hox homeodomain amino-terminal arms establishes different DNA-binding specificities across the Hox locus. Mol. Cell. Biol. 16: 1734-1745; 1996.

Chang C. P.; Shen W. F.; Rozenfeld S.; Lawrence H. J.; Largman C.; Cleary M. L. Pbx proteins display hexapeptide-dependent cooperative DNA binding with a subset of Hox proteins. Genes Dev. 9: 663-674; 1995. doi:10.1101/gad.9.6.663.

Chui D.; Oh-Eda M.; Liao Y. F.; Panneerselvam K.; Lal A.; Marek K. W.; Freeze H. H.; Moremen K. W.; Fukuda M. N.; Marth J. D. Alpha-mannosidase-II deficiency results in dyserythropoiesis and unveils an alternate pathway in oligosaccharide biosynthesis. Cell 90: 157-167; 1997. doi:10.1016/S0092-8674(00)80322-0.

D'Agostino D.; Cordle R. A.; Kullman J.; Erlanson-Albertsson C.; Muglia L. J.; Lowe M. E. Decreased postnatal survival and altered body weight regulation in procolipase-deficient mice. J. Biol. Chem. 277: 7170-7177; 2002. doi:10.1074/jbc.M108328200.

DiMartino J. F.; Selleri L.; Traver D.; Firpo M. T.; Rhee J.; Warnke R.; O'Gorman S.; Weissman I. L.; Cleary M. L. The Hox cofactor and proto-oncogene $\mathrm{Pbx} 1$ is required for maintenance of definitive hematopoiesis in the fetal liver. Blood 98: 618-626; 2001. doi:10.1182/blood.V98.3.618.

Falk A.; Frisen J. Amphiregulin is a mitogen for adult neural stem cells. J. Neurosci. Res. 69: 757-762; 2002. doi:10.1002/jnr.10410.

Fraichard A.; Chassande O.; Bilbaut G.; Dehay C.; Savatier P.; Samarut J. In vitro differentiation of embryonic stem cells into glial cells and functional neurons. J. Cell Sci. 108: 3181-3188; 1995.

Gajovic S.; St-Onge L.; Yokota Y.; Gruss P. Retinoic acid mediates Pax6 expression during in vitro differentiation of embryonic stem cells. Differentiation 62: 187-192; 1997. doi:10.1046/j.14320436.1998.6240187.x.

Gittes G. K.; Galante P. E.; Hanahan D.; Rutter W. J.; Debase H. T. Lineage-specific morphogenesis in the developing pancreas: role of mesenchymal factors. Development 122: 439-447; 1996.

Goudet G.; Delhalle S.; Biemar F.; Martial J. A.; Peers B. Functional and cooperative interactions between the homeodomain PDX1, 
Pbx, and Prep1 factors on the somatostatin promoter. J. Biol. Chem. 274: 4067-4073; 1999. doi:10.1074/jbc.274.7.4067.

Hasegawa H.; Lian S. C.; Finkbeiner W. E.; Verkman A. S. Extrarenal tissue distribution of CHIP28 water channels by in situ hybridization and antibody staining. Am. J. Physiol. 266: C893-C903; 1994.

Jabet C.; Gitti R.; Summers M. F.; Wolberger C. NMR studies of the pbx 1 TALE homeodomain protein free in solution and bound to DNA: proposal for a mechanism of HoxB1-Pbx1-DNA complex assembly. J. Mol. Biol. 291: 521-530; 1999. doi:10.1006/jmbi.1999.2983.

Jonsson J.; Carlsson L.; Edlund T.; Edlund H. Insulin-promoter-factor 1 is required for pancreas development in mice. Nature 371: 606-609; 1994. doi:10.1038/371606a0.

Kato K. Finding new genes in the nervous system by cDNA analysis. Trends Neurosci. 15: 319-323; 1992. doi:10.1016/0166-2236(92) 90046-B.

Kido Y.; Nakae J.; Hribal M. L.; Xuan S.; Efstratiadis A.; Accili D. Effects of mutations in the insulin-like growth factor signaling system on embryonic pancreas development and beta-cell compensation to insulin resistance. J. Biol. Chem. 277: 36740 36747; 2002. doi:10.1074/jbc.M206314200.

Kim S. K.; Selleri L.; Lee J. S.; Zhang A. Y.; Gu X.; Jacobs Y.; Cleary M. L. Pbx1 inactivation disrupts pancreas development and in Ipf1-deficient mice promotes diabetes mellitus. Nat. Genet. 30: 430-435; 2002. doi:10.1038/ng860.

Knoepfler P. S.; Calvo K. R.; Chen H.; Antonarakis S. E.; Kamps M. P. Meis 1 and pKnox 1 bind DNA cooperatively with Pbx1 utilizing an interaction surface disrupted in oncoprotein E2aPbx1. Proc. Natl. Acad. Sci. U. S. A. 94: 14553-14558; 1997. doi:10.1073/pnas.94.26.14553.

Knoepfler P. S.; Kamps M. P. The Pbx family of proteins is strongly upregulated by a post-transcriptional mechanism during retinoic acid-induced differentiation of P19 embryonal carcinoma cells. Mech. Dev. 63: 5-14; 1997. doi:10.1016/S0925-4773(97)00669-2.

Kojima N.; Yoshida Y.; Kurosawa N.; Lee Y. C.; Tsuji S. Enzymatic activity of a developmentally regulated member of the sialyltransferase family (STX): evidence for alpha 2,8-sialyltransferase activity toward N-linked oligosaccharides. FEBS Lett. 360: 1-4; 1995a. doi:10.1016/0014-5793(95)00059-I.

Kojima N.; Yoshida Y.; Tsuji S. A developmentally regulated member of the sialyltransferase family (ST8Sia II, STX) is a polysialic acid synthase. FEBS Lett. 373: 119-122; 1995b. doi:10.1016/ 0014-5793(95)01024-9.

Kuerbitz S. J.; Pahys J.; Wilson A.; Compitello N.; Gray T. A. Hypermethylation of the imprinted NNAT locus occurs frequently in pediatric acute leukemia. Carcinogenesis 23: 559-564; 2002. doi:10.1093/carcin/23.4.559.

Laborda J. The role of the epidermal growth factor-like protein dlk in cell differentiation. Histol. Histopathol. 15: 119-129; 2000.

LaRonde-LeBlanc N. A.; Wolberger C. Structure of HoxA9 and Pbx1 bound to DNA: Hox hexapeptide and DNA recognition anterior to posterior. Genes Dev. 17: 2060-2072; 2003. doi:10.1101/ gad.1103303.

Lee G.; Cowan N.; Kirschner M. The primary structure and heterogeneity of tau protein from mouse brain. Science 239: 285-288; 1988. doi:10.1126/science.3122323.

Leighton P. A.; Ingram R. S.; Eggenschwiler J.; Efstratiadis A.; Tilghman S. M. Disruption of imprinting caused by deletion of the H19 gene region in mice. Nature 375: 34-39; 1995. doi:10.1038/375034a0.

Lescisin K. R.; Varmuza S.; Rossant J. Isolation and characterization of a novel trophoblast-specific cDNA in the mouse. Genes Dev. 2: 1639-1646; 1988. doi:10.1101/gad.2.12a.1639.

Li E.; Beard C.; Jaenisch R. Role for DNA methylation in genomic imprinting. Nature 366: 362-365; 1993. doi:10.1038/366362a0.
Lin S. P.; Youngson N.; Takada S.; Seitz H.; Reik W.; Paulsen M.; Cavaille J.; Ferguson-Smith A. C. Asymmetric regulation of imprinting on the maternal and paternal chromosomes at the Dlk1-Gt12 imprinted cluster on mouse chromosome 12. Nat. Genet. 35: 97-102; 2003. doi:10.1038/ng1233.

Lu Q.; Kamps M. P. Structural determinants within Pbx1 that mediate cooperative DNA binding with pentapeptide-containing Hox proteins: proposal for a model of a Pbx1-Hox-DNA complex. Mol. Cell. Biol. 16: 1632-1640; 1996.

Mann R. S.; Chan S. K. Extra specificity from extradenticle: the partnership between HOX and PBX/EXD homeodomain proteins. Trends Genet. 12: 258-262; 1996. doi:10.1016/0168-9525(96)10026-3.

Niwa H.; Miyazaki J.; Smith A. G. Quantitative expression of Oct-3/4 defines differentiation, dedifferentiation or self-renewal of ES cells. Nat. Genet. 24: 372-376; 2000. doi:10.1038/74199.

Okabe S.; Forsberg-Nilsson K.; Spiro A. C.; Segal M.; McKay R. D. Development of neuronal precursor cells and functional postmitotic neurons from embryonic stem cells in vitro. Mech. Dev. 59: 89-102; 1996. doi:10.1016/0925-4773(96)00572-2.

Peltenburg L. T.; Murre C. Engrailed and Hox homeodomain proteins contain a related $\mathrm{Pbx}$ interaction motif that recognizes a common structure present in Pbx. EMBO J. 15: 3385-3393; 1996.

Peltenburg L. T.; Murre C. Specific residues in the Pbx homeodomain differentially modulate the DNA-binding activity of Hox and Engrailed proteins. Development 124: 1089-1098; 1997.

Piper D. E.; Batchelor A. H.; Chang C. P.; Cleary M. L.; Wolberger C. Structure of a HoxB1-Pbx1 heterodimer bound to DNA: role of the hexapeptide and a fourth homeodomain helix in complex formation. Cell 96: 587-597; 1999. doi:10.1016/S0092-8674(00) 80662-5.

Qin P.; Haberbusch J. M.; Zhang Z.; Soprano K. J.; Soprano D. R. Pre-B cell leukemia transcription factor (PBX) proteins are important mediators for retinoic acid-dependent endodermal and neuronal differentiation of mouse embryonal carcinoma P19 cells. J. Biol. Chem. 279: 16263-16271; 2004. doi:10.1074/jbc. M313938200.

Quattrocchi C. C.; Huang C.; Niu S.; Sheldon M.; Benhayon D.; Cartwright J. Jr.; Mosier D. R. Jr.; Keller F.; D’Arcangelo G. Reelin promotes peripheral synapse elimination and maturation. Science 301: 649-653; 2003. doi:10.1126/science.1082690.

Redmond L.; Hockfield S.; Morabito M. A. The divergent homeobox gene PBX1 is expressed in the postnatal subventricular zone and interneurons of the olfactory bulb. J. Neurosci. 16: 2972-2982; 1996.

Rhee J. W.; Arata A.; Selleri L.; Jacobs Y.; Arata S.; Onimaru H.; Cleary M. L. Pbx3 deficiency results in central hypoventilation. Am. J. Pathol. 165: 1343-1350; 2004.

Rose M. I.; Crisera C. A.; Colen K. L.; Connelly P. R.; Longaker M. T.; Gittes G. K. Epithelio-mesenchymal interactions in the developing mouse pancreas: morphogenesis of the adult architecture. J. Pediatr. Surg. 34: 774-779; 1999, discussion 780. doi:10.1016/S0022-3468(99)90372-X.

Saleh M.; Huang H.; Green N. C.; Featherstone M. S. A conformational change in PBX1A is necessary for its nuclear localization. Exp. Cell Res. 260: 105-115; 2000a. doi:10.1006/ excr.2000.5010.

Saleh M.; Rambaldi I.; Yang X. J.; Featherstone M. S. Cell signaling switches HOX-PBX complexes from repressors to activators of transcription mediated by histone deacetylases and histone acetyltransferases. Mol. Cell. Biol. 20: 8623-8633; $2000 \mathrm{~b}$. doi:10.1128/MCB.20.22.8623-8633.2000.

Sanvito F.; Herrera P. L.; Huarte J.; Nichols A.; Montesano R.; Orci L.; Vassalli J. D. TGF-beta 1 influences the relative development of the exocrine and endocrine pancreas in vitro. Development 120: 3451-3462; 1994. 
Sato T. N.; Qin Y.; Kozak C. A.; Audus K. L. Tie-1 and tie-2 define another class of putative receptor tyrosine kinase genes expressed in early embryonic vascular system. Proc. Natl. Acad. Sci. U. S. A. 90: 9355-9358; 1993. doi:10.1073/pnas.90.20.9355.

Schmidt J. V.; Matteson P. G.; Jones B. K.; Guan X. J.; Tilghman S. M. The Dlk1 and Gtl2 genes are linked and reciprocally imprinted. Genes Dev. 14: 1997-2002; 2000.

Schnabel C. A.; Godin R. E.; Cleary M. L. Pbx1 regulates nephrogenesis and ureteric branching in the developing kidney. Dev. Biol. 254: 262-276; 2003a. doi:10.1016/S0012-1606(02)00038-6.

Schnabel C. A.; Selleri L.; Cleary M. L. Pbx1 is essential for adrenal development and urogenital differentiation. Genesis 37: 123 130; 2003b. doi:10.1002/gene.10235.

Schnabel C. A.; Selleri L.; Jacobs Y.; Warnke R.; Cleary M. L. Expression of $\mathrm{Pbx} 1 \mathrm{~b}$ during mammalian organogenesis. Mech. Dev. 100: 131-135; 2001. doi:10.1016/S0925-4773(00)00516-5.

Selleri L.; Depew M. J.; Jacobs Y.; Chanda S. K.; Tsang K. Y.; Cheah K. S.; Rubenstein J. L.; O'Gorman S.; Cleary M. L. Requirement for $\mathrm{Pbx} 1$ in skeletal patterning and programming chondrocyte proliferation and differentiation. Development 128: 3543-3557; 2001.

Shen W. F.; Chang C. P.; Rozenfeld S.; Sauvageau G.; Humphries R. K.; Lu M.; Lawrence H. J.; Cleary M. L.; Largman C. Hox homeodomain proteins exhibit selective complex stabilities with Pbx and DNA. Nucleic Acids Res. 24: 898-906; 1996. doi:10.1093/nar/24.5.898.

Shen W. F.; Rozenfeld S.; Lawrence H. J.; Largman C. The Abd-Blike Hox homeodomain proteins can be subdivided by the ability to form complexes with Pbxla on a novel DNA target. J. Biol. Chem. 272: 8198-8206; 1997. doi:10.1074/jbc.272.13.8198.

Srivastava M.; Hsieh S.; Grinberg A.; Williams-Simons L.; Huang S. P.; Pfeifer K. H19 and Igf2 monoallelic expression is regulated in two distinct ways by a shared cis acting regulatory region upstream of H19. Genes Dev. 14: 1186-1195; 2000.
Stock M.; Schafer H.; Stricker S.; Gross G.; Mundlos S.; Otto F. Expression of galectin-3 in skeletal tissues is controlled by Runx2. J. Biol. Chem. 278: 17360-17367; 2003. doi:10.1074/jbc.M207631200.

Takada S.; Paulsen M.; Tevendale M.; Tsai C. E.; Kelsey G.; Cattanach B. M.; Ferguson-Smith A. C. Epigenetic analysis of the Dlk1-Gt12 imprinted domain on mouse chromosome 12: implications for imprinting control from comparison with Igf2-H19. Hum. Mol. Genet. 11: 77-86; 2002. doi:10.1093/hmg/11.1.77.

Takada S.; Tevendale M.; Baker J.; Georgiades P.; Campbell E.; Freeman T.; Johnson M. H.; Paulsen M.; Ferguson-Smith A. C. Delta-like and gtl2 are reciprocally expressed, differentially methylated linked imprinted genes on mouse chromosome 12 . Curr. Biol. 10: 1135-1138; 2000. doi:10.1016/S0960-9822(00) 00704-1.

Uchida N.; Shimamura K.; Miyatani S.; Copeland N. G.; Gilbert D. J.; Jenkins N. A.; Takeichi M. Mouse alpha N-catenin: two isoforms, specific expression in the nervous system, and chromosomal localization of the gene. Dev. Biol. 163: 75-85; 1994. doi:10.1006/dbio.1994.1124.

Van Wyk J. J.; Smith E. P. Insulin-like growth factors and skeletal growth: possibilities for therapeutic interventions. J. Clin. Endocrinol. Metab. 84: 4349-4354; 1999. doi:10.1210/ jc.84.12.4349.

Wasserman P. M.; Abelson J. N.; DePamphilis M. L.; Simon M. L. Guide to techniques in mouse development. In: Abelson J. N. (ed) Methods in enzymology. Academic, San Diego, pp 858-868; 1993.

Ying Q. L.; Nichols J.; Chambers I.; Smith A. BMP induction of Id proteins suppresses differentiation and sustains embryonic stem cell self-renewal in collaboration with STAT3. Cell 115: 281292; 2003. doi:10.1016/S0092-8674(03)00847-X.

Zumkeller W.; Burdach S. The insulin-like growth factor system in normal and malignant hematopoietic cells. Blood 94: 3653-3657; 1999. 